each in turn divided into basins, and the Pacific Ocean divided into a wide central trough and narrow western and (south) eastern troughs. A second map divides the surface waters on the same basis and gives a name to the sea overlying each basin. This is of more doubtful value, and some of the names are unlikely to gain general acceptance.

\section{Bathymetric Charts of the Oceans}

AT the Seventh International Oceanographical Congress held in Berlin in 1899 it was decided to draw up a general bathymetric chart of the oceans. Through the generosity of H.S.H. Prince Albert I of Monaco, it was possible to produce the first edition in 1904 and a second edition which was begun in 1912 but not completed until 1930. After the death of the Prince of Monaco, it was decided that a new edition should be prepared by the International Hydrographic Bureau at Monte Carlo. The first sheet of this third edition, Sheet $A .1$ (North Atlantic from Equator to lat. $47^{\circ} \mathrm{N}$.), is now on sale at a price of 35 French francs. Since the publication of the last edition, echo-sounding has come into general practice, and in the construction of Sheet $A .1$ some 70,000 soundings were examined. As a result, the many inequalities of the bottom of the sea are now being disclosed in areas previously thought to be more or less smooth. The sheet $(1 \mathrm{ft} .11 \mathrm{in}$. by $3 \mathrm{ft}$. 3 in., chart dimensions) is coloured to show the depth contours of the ocean and the principal mountain ranges of the continents.

\section{Forty-Six Years of Phenology}

Mr. J. Edmund ClaRK's important paper on "The History of British Phenology" (Quart. J. Roy. Meteorol. Soc., 62, January 1936) comes at a time when the six hundred or so phenological observers organised in Britain by the Royal Meteorological Society are beginning their annual observations on the dates of flowering of plants, song of birds, appearance of migrants, butterflies, etc. In Great Britain organised phenology dates from Gilbert White's classic eighteenth century observations. The Royal Meteorological Society's phenological reports were begun in 1875 by the Rev. Thomas A. Preston, of Marlborough School, who made about 20,000,000 calculations. From 1889 until 1910 Edward Mawley organised them with 22-23 observing stations watching 50 plants, 14 birds, 6 insects and frog spawn. From 1911 until 1913, Messrs. J. E. Clark and R. H. Hooker were responsible, in $1914 \mathrm{Mr}$. Clark, and from 1915 until 1920 (during which year 5,000 reports were tabulated) by Messrs. J. E. Clark and H. B. Adames. For the last five years, Messrs. J. E. Clark, I. D. Margary and C. J. P. Cave have been responsible for them, and in 1930 as many as 18,000 records were tabulated. Critics of the exhaustive series of statistics and maps published annually in the Phenological Report will probably, after the half century of work is reached, appreciate their value in that the deductions are already proving useful for farm and garden crops.

\section{Central Agricultural and Scientific Bibliography}

MODERN mass-production of scientific and technical literature led first to the growth of comprehensive abstract services, which, as literary proliferation increased, have tended to bury the references to articles on specific subjects in the mass of abstracts on all subjects. Thus has developed the presentday demand for specialised bibliographies-lists of references classified according to the titles of the articles noticed, and informing about the quantity rather than the quality of scientific literature. A comprehensive bibliography on all branches of agriculture and allied subjects is now being organised at the Science Library, South Kensington, London, S.W.7. As the Library takes most of the four thousand or so agricultural journals published throughout the world, it offers unusually good facilities for the preparation of such a bibliography. Subscribers, paying $10 s$. per annum as individuals, or $£ 55 s$. as institutions, will have full access to the bibliography and special facilities for reference to books in the Library. Translations and abstracts will also be made. The service commenced on March 1.

\section{The Applications of Fluorescence}

IN a paper read to the Illuminating Engineering Society on January 14, Mr. F. E. Lamplough pointed out some useful applications of fluorescence. The work is carried out both by visual and photographic methods, and as the fluorescence colours as a rule bear little relation to the natural colours of substances, it often happens that colourless materials and those of identical natural colours can readily be distinguished by their fluorescence. This method is used by detectives, experts and collectors. It has been used for deciphering ancient manuscripts from which the writing had been erased, for detecting alterations in pictures, for distinguishing between old and now marble, cut ivory or bone. Repairs to pottery, glass and woodwork are at once evident. It is of equal value in the examination of foodstuffs, textiles and paper. It has been used to yield pictures of fossils otherwise almost invisible. Some use of it has been made in display and advertising as well as in stage and film work. Extensive use was made of fluorescence in the film production of H. G. Wells's "Invisible Man". If the skin of the actor is made non-fluorescent and his suit strongly fluorescent, then in ultra-violet light the suit appears to walk about in the most amazing manner without visible means of support. The use of fluorescence to vary the colour of a source of light was demonstrated by means of a series of discharge tubes, in which the light given by the discharge was changed by coating the interior of the tube with different fluorescent powders.

\section{Biochemical Research in India}

The annual report of the Indian Society of Biological Chemists gives as usual a comprehensive summary of the work carried out during the past year (Society of Biological Chemists, India. Biochemical and Allied Research in India in 1934. 